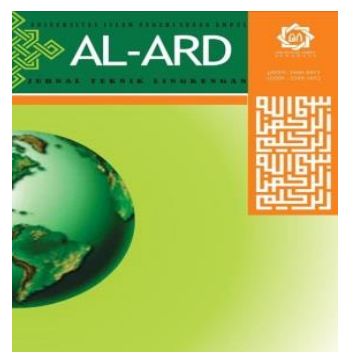

Al-Ard: Jurnal Teknik Lingkungan

Vol.7 No.1 - September 2021 (hal. 25-32)

http://jurnalsaintek.uinsby.ac.id/index.php/alard/index
Al-Ard:

Jurnal

Teknik Lingkungan

\title{
Pembuatan Pupuk Organik dari Eceng Gondok, Kotoran Sapi, dan Dedak Padi dengan Effective Microorganisme 4 (Em4)
}

\section{Sri Widyastuti ${ }^{1,}$, Risa Suryananta Arfa $^{2}$}

1,2Program Studi Teknik Lingkungan, Fakultas Teknik Sipil dan Perencanaan

Universitas PGRI Adi Buana Surabaya, Surabaya, Indonesia

*sriwidyastuti@unipasby.ac.id

\begin{abstract}
Water hyacinth (Eichonia crassipes) is one of the fastest growing aquatic plants. As a result, it will cover the surface of the water and prevent sunlight from entering the water. The inhibition of sunlight causes aquatic biota cannot carry out photosynthesis perfectly so that water hyacinth is considered as a weed. This research aims to analyzed the quality of water hyacinth organic fertilizer based on the type of additives in order to obtain the best quality in composting for 16 days. Additional materials used are cow dung and rice bran. The parameters used to determine the quality of the organic fertilizer produced are the value of $\mathrm{C} / \mathrm{N}$ ratio, levels of Phosphorus (P), Potassium (K), pH, and temperature (T). The variety of materials used in the Control Reactor (RK) contains $1.5 \mathrm{~kg}$ of water hyacinth; Treatment Reactor 1 (R1) contains $0.5 \mathrm{~kg}$ of water hyacinth $+1 \mathrm{~kg}$ of cow dung; Treatment Reactor 2 (R2) contains $0.5 \mathrm{~kg}$ of water hyacinth $+1 \mathrm{~kg}$ of rice bran; and Treatment Reactor 3 (R3) contains $0.5 \mathrm{~kg}$ of water hyacinth $+1 \mathrm{~kg}$ of cow dung $+1 \mathrm{~kg}$ of rice bran. In each treatment, effective microorganism 4 (EM4) bioactivator was added. The results showed that Treatment 3 (R3) produced organic fertilizer with quality that met the quality standards of the Decree of the Minister of Agriculture Number 261/KPTS/SR.310/M/4/2019 regarding the technical requirements of organic fertilizer.
\end{abstract}

Keywords : Water hyacinth, Cow dung, Fertilizers quality, Organic fertilizers

\begin{abstract}
Abstrak
Eceng gondok (Eichonia crassipes) adalah salah satu tumbuhan air yang memiliki pertumbuhan yang cepat. Akibatnya akan menutup permukaan air dan menghambat cahaya matahari masuk ke air. Terhambatnya cahaya matahari menyebabkan biota air tidak dapat melakukan fotosintesis dengan sempurna sehingga enceng gondok di anggap sebagai gulma. Penelitian ini bertujuan untuk

menganalisis kualitas pupuk organik eceng gondok berdasarkan jenis bahan tambahan sehingga diperoleh kualitas terbaik pada pengomposan selama 16 hari. Bahan tambahan yang di gunakan adalah kotoran sapi dan dedak padi. Parameter yang digunakan mengetahui kualitas pupuk organik yang dihasilkan adalah nilai $\mathrm{C} / \mathrm{N}$ rasio, kadar Phosfor (P), Kalium (K), pH, dan temperatur (T). Variasi bahan yang digunakan pada Reaktor Kontrol (RK) berisi 1,5 kg Eceng gondok; Reaktor Perlakuan 1 (R1) berisi 0,5 kg eceng gondok $+1 \mathrm{~kg}$ kotoran sapi; Reaktor Perlakuan 2 (R2) berisi 0,5 kg eceng gondok +1 kg dedak padi; dan Reaktor Perlakuan 3 (R3) berisi $0,5 \mathrm{~kg}$ eceng gondok $+1 \mathrm{~kg}$ kotoran sapi $+1 \mathrm{Kg}$ dedak padi. Pada setiap perlakuan ditambahkan bioaktivator effective microorganism 4 (EM4). Hasil penelitian menunjukkan Perlakuan 3 (R3) menghasilkan pupuk organik dengan kualitas yang memenuhi syarat baku mutu Keputusan Menteri Pertanian Nomor 261/KPTS/SR.310/M/4/2019 tentang persyaratan teknis pupuk organik.

Kata kunci : eceng gondok, kotoran sapi, dedak padi, pupuk organik padat .
\end{abstract}

\section{PENDAHULUAN}

Keberadaan beberapa tumbuhan merupakan masalah di perairan karena tingkat pertumbuhannya relatif cepat, seperti purun tikus (Eleocharis dulcis), kalakai (Stenochlaena palustris), dan eceng gondok (Eichornia crassipes). Tumbuhan-tumbuhan tersebut merupakan jenis tanaman yang paling umum dikenal dan sering ditemukan di ekosistem lahan rawa sebagai gulma atau tanaman liar (Ellya et al., 2020)

Eceng gondok memiliki kecepatan tumbuhan yang tinggi, mengambil ruang dalam badan dan menutup cahaya matahari sehingga dianggap sebagai tumbuhan pengganggu. Mampu menutup 20\%-70\% dari luas perairan (Kartini,2017). Menurut Heyne, K (1987) dalam (Yani, 2018), eceng gondok mampu 
menghasilkan 1200 anakan dalam waktu 4 bulan dengan produksi 470 ton/hektar.

Eceng gondok sangat sulit untuk dimusnahkan sehingga harus dilakukanlah alternatif lain untuk menurunkan produktivitasnya dengan mengolah eceng gondok sebagai bahan baku pembuatan pupuk organik untuk penyubur tanaman (Mashavira et al., 2015 ; Nada dkk, 2012).

Pilihan untuk mengolah menjadi pupuk organik adalah karena keunggulan pupuk organik dalam menyediakan hara bagi tanaman, baik hara makro maupun mikro yang relatif lengkap dibanding pupuk anorganik. Meningkatkan kesuburan tanah, menambah unsur hara mikro tanah, menggemburkan tanah, memperbaiki kemasaman tanah, meningkatkan kemampuan tanah dalam menyediakan oksigen bagi perakaran. Bahan organik dalam pupuk akan memacu pertumbuhan dan perkembangan bakteri dan biota tanah. Secara umum pupuk organik berguna bagi konservasi lahan kritis yang semakin meluas di Indonesia ( Juliani, 2017)

Keuntungan lain adalah dapat memperbaiki porositas tanah dan memperbesar kemampuan tanah menampung air (Nengse S, 2017).

Kusrinah, et al., (2016) mmelaporkan bahwa eceng gondok kering mengandung bahan organik sebesar $75,8 \%$; total nitrogen 1,5\%; kadar abu $24,2 \%$; total phospor $7,0 \%$; potasium $28,7 \%$; sodium 1,8\%; kalsium 12,8\% dan khlorida $21,0 \%$

Komposisi C,N, P dan K tersebut di perlukan dalam proses pertumbuhan tana-mansebagai unsur hara sehingga eceng gondok dapat diolah menjadi pupuk organik.

Penelitian Setiawan (2009) dilakukan dengan mencampurkan eceng gondok dengan pupuk kandang sapi serta menambahkan EM-4 memiliki kandungan $\mathrm{C} / \mathrm{N}$ rasio sebesar 12,87 dimana lama dekomposisi selama 6 minggu. Sedangkan eceng gondok yang di dekomposisi tanpa tambahan apapun memiliki $\mathrm{C} / \mathrm{N}$ rasio sebesar 18,00.

Pupuk organik berbahan eceng gondok hasil penelitian Fitrihidajati (2015) tanpa tambahan bahan apapun memiliki kandungan $\mathrm{P}$ sebesar $0,184 \%$, Kalium $=0,226 \%$ dan $\mathrm{C} / \mathrm{N}$ rasio sebesar 17,44.

Pembuatan pupuk organik eceng gondok dengan aktivator selain EM-4 menunjukkan hasil penelitian yang bervaraisi. Penelitian Turnip (2016) dengan mencampurkan eceng gondok dan pupuk kandang sapi ditambah inokulan jamur Trichoderma harzianum menghasilkan $\mathrm{C} / \mathrm{N}$ rasio sebesar 20 , Phospor $(\mathrm{P} 205)=0,10 \%, \mathrm{~K}_{2} \mathrm{O}=0,20(\%)$.

Hasil analisis jaringan eceng gondok setelah difermentasi aktivator Trichoderma sp menunjukkan $\mathrm{pH}=6,8 ; \quad \mathrm{C} / \mathrm{N}$ ratio $=13, \mathrm{P}$ total $=-$ $0,58 \%$, dan $\mathrm{K}$ total $=0,33 \%$ (Pujowati et al, 2019).

Campuran bahan kotoran kandang sapi, eceng gondok, kalsium dan diinokulasi dengan konsorsium bakteri dari genera Pseudomonas sp. dan Bacillus sp. Menghasilkan C/N rasio sebesar 14,0 , P2O5 0,729\%, dan K2O 2,090\% (Sondang, 2020)

Penelitian Ellya (2020) menunjukkan nilai kandungan $\mathrm{C} / \mathrm{N}$ rasio pada pengomposan eceng gondok saja sebesar $24,05 \%$.

Nilai C/N rasio penelitian diatas meski-pun telah memenuhi persyaratan sebagai pupuk organik , namun harga tersebut masih jauh dari nilai $\mathrm{C} / \mathrm{N}$ tanah sebesar 10-12.

Sehingga perlu dilakukan penelitian terhadap kualitas pupuk organik eceng gondok dengan bahan tambahan yang mampu menghasilkan kualitas sesuai baku mutu pupuk organik berdasarkan Keutusan Menteri Pertanian No 261/KPTS/SR.310/M/4/2019 serta penambahan bioaktivator yang membantu proses dekomposisi .

Bahan yang di tambahkan adalah kotoran sapi dan dedak padi . Kotoran sapi mengandung sejumlah mikroba dekomposer yang dapat menguraikan bahan organik untuk mempercepat proses pengomposan. Kadar serat yang tinggi seperti selulosa merupakan media yang baik bagi pertumbuhan mikroba yang akan membantu proses dekomposisi eceng gondok (Krismawati, 2014; Melsasail, 2019).

Dedak padi mempunyai kandungan serat kasar yang cukup tinggi yaitu sebesar $24,26 \%$, dalam proses dekomposisi berfungsi sebagai media untuk pembiakan mikroorganisme (Kleden et al., 2017; Amnah, 2019; Tahun,2019).

Proses dekomposisi akan mengubah bahan organik kompleks menjadi bahan organik sederhana dan di ubah menjadi bentuk mineral yang mudah diserap oleh tanaman atau organisme lain (Palupi, 2015). Proses untuk mempercepat pengomposan dapat dipacu dengan pemberian mikroorganisme sebagai dekomposer (Karyono, et. al, 2017). Jumlah dan jenis mikroorganisme yang efektif mengubah bahan organik kompleks akan menentukan keberhasilan proses 
pengomposan, seperti halnya bio aktivator Effective Microorganism (EM4). EM-4 merupakan cairan yang mengandung mikroorganisme fermentasi yang terdiri dari 80 genus mikroba dan dapat bekerja secara efektif dalam fermentasi bahan organik. Kultur campuran EM-4 terdiri dari 5 golongan yang pokok, yaitu bakteri fotosintetik, Lactobacillus $s p$, Saccharomyces sp, Actinomycetes sp dan jamur fermentasi (Jalaluddin, 2016; Pinandita, et. al., 2017).

Tujuan dari penelitian ini adalah untuk menganalisis kualitas pupuk organik eceng gondok berdasarkan jenis bahan tambahan sehingga ditemukan kualitas terbaik pada pengomposan selama 16 hari. Bahan yang ditambahkan adalah kotoran sapi, dan dedak padi. Bioaktivator effective microorganism 4 (EM4) ditambahkan pada semua perlakuan. Parameter kualitas pupuk organik yang diamati adalah nilai $\mathrm{C} / \mathrm{N}$ rasio, Phospor (P), Kalium (K), pH dan suhu kompos.

\section{METODE PENELITIAN}

Alat - alat yang digunakan dalam penelitian ini antara lain reaktor, saringan yang terbuat dari fiber untuk menyaring lindi, selang bening, ember, timbangan, pisau, thermometer, soil tester dan botol bekas.

Bahan - bahan yang digunakan adalah eceng gondok, kotoran sapi, dedak padi, dan effective microorganism 4 (EM4).

Tahapan dalam penelitian ini adalah memperkecil eceng gondok agar proses dekomposisi berjalan sempurna. Langkah berikutnya adalah proses dekomposisi dengan 4 (empat) perlakuan, terdiri dari Perlakuan kontrol (RK) : berisi 1,5 kg eceng gondok saja, Perlakuan 1 (R1 ) : berisi 0,5 kg eceng gondok $+1 \mathrm{~kg}$ kotoran sapi, Perlakuan 2 (R2) : berisi $0,5 \mathrm{~kg}$ eceng gondok $+1 \mathrm{~kg}$ dedak padi, Perlakuan 3 (R3) : berisi 0,5 eceng gondok +1 $\mathrm{kg}$ kotoran sapi $+1 \mathrm{~kg}$ dedak padi. Larutan EM4 sebanyak $200 \mathrm{~mL}$ ditambahkan pada masing masing perlakuan, selanjutnya dilakukan dekomposisi selama 16 hari.

\section{Parameter pengamatan}

Parameter yang diukur sebagai indikator kualitas pupuk organik adalah $\mathrm{C} / \mathrm{N}$ rasio, Phospor (P), Kalium (K) dan $\mathrm{pH}$ sesuai dengan Keputusan Menteri Pertanian Nomor 261/KPTS/-SR.310/M/4/2019.

Sedangkan parameter suhu menggunakan SNI 19-7030-2004 Spesifikasi Kompos dari Sampah Organik Domestik karena pada
Keputusan Menteri Pertanian Nomor 261/KPTS/SR.310/M/4/2019 tidak ada aturan tentang suhu .

Pada hari ke-7 dilakukan pengamatan secara fisik berupa pengamatan $\mathrm{pH}$ dan temperatur sampai hari terakhir pengomposan.

Penentuan kandungan kadar C-organik dilakukan dengan menggunakan metode Walkley and Black Spektrometry. Penentuan kandungan kadar nitrogen dila-kukan dengan menggunakan metode Kjeldahl. Pengukuran rasio $\mathrm{C} / \mathrm{N}$ dilakukan dengan perbandingan $\%$ kadar C-organik dan \% nitrogen (AOAC , 2016 dalam Permentan Nomor 261/KPTS/SR.310/M/4/2019)

Penetapan Kadar Phospor $\left(\mathrm{P}_{2} \mathrm{O}_{5}\right)$ dan Kalium $\left(\mathrm{K}_{2} \mathrm{O}\right)$ diukur dengan spektro-photometer pada panjang gelombang $466 \mathrm{~nm}$ dengan deret standar P dan K sebagai pembanding

\section{HASIL DAN PEMBAHASAN}

\subsection{Pengaruh Kombinasi Bahan Baku terhadap $\mathrm{C} / \mathrm{N}$ rasio}

Rasio C/N merupakan salah satu parameter kualitas kompos berdasarkan tingkat kematangan kompos. Tingkat kema-tangan kompos diukur berdasarkan penu-runan nilai rasio $\mathrm{C} / \mathrm{N}$ yang disebabkan oleh aktivitas degradasi mikroba yang terdapat pada bahan tambahan seperti kotoran sapi dan bioaktivator kompos pada bahan baku pupuk organik (Tripetchkul, 2012).

Pada proses perombakan bahan organik, mikroba akan tumbuh dan memperbanyak diri dengan menggunakan C (karbon) sebagai bahan bakunya. Karbon akan digunakan sebagai sumber energi untuk menyusun sel mikroba dengan membebaskan $\mathrm{CO} 2$ dan gas lain yang mudah menguap seperti metana serta senyawa lain nya. Kadar karbon akan cenderung menurun setelah proses dekomposisi. Kecepatan kehilangan karbon lebih besar daripada kehilangan nitrogen. Sehingga diperoleh perimbangan $\mathrm{C} / \mathrm{N}$ berkisar antara 15-25 yang menunjukkan pupuk organik telah matang.

Unsur nitrogen pada pupuk organik diperoleh dari peruraian bahan organik yang berbasis protein. Peruraian bahan yang mengandung unsur nitrogen, pertama di uraikan menjadi asam amino terlebih dahulu baru diuraikan menjadi unsur nitrogen (Buckman, 1982). Selama proses dekomposisi unsur nitrogen digunakan untuk pemeliharaan dan penyusunan sel mikroba. Hasil penelitian Yani (2018) menunjukkan nilai rata rata $\mathrm{N}$ - 
total pada pupuk organik yang di tambahkan bioaktivator akan lebih tinggi dibandingkan dengan pupuk organik yang tidak diberi bioaktivator pada saat proses dekomposisi

Kadar C/N rasio pada pengaruh jenis bahan baku dapat dilihat pada Gambar 1 di bawah ini:

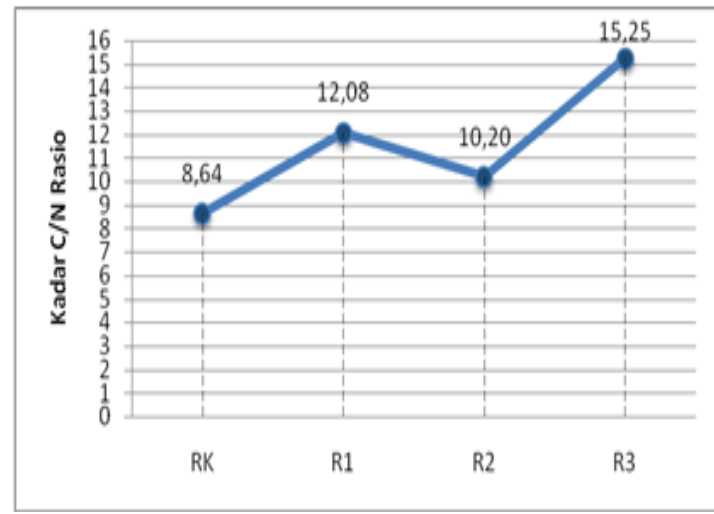

Gambar 1. Pengaruh Variasi Bahan Baku terhadap C/N Rasio

Pada Gambar 1, variasi bahan baku menghasilkan $\mathrm{C} / \mathrm{N}$ Rasio yang signifikan. Pengaruh variasi jumlah bahan baku menghasilkan nilai $\mathrm{C} / \mathrm{N}$ rasio tertinggi pada reaktor tiga (R3) dengan 3 jenis bahan baku yaitu sebesar $15,25 \%$ dan nilai terendah pada reaktor kontrol (RK) dengan 1 jenis bahan baku yaitu sebesar 8,64\%.

Variasi 3 jenis bahan baku meng-hasilkan $\mathrm{C} / \mathrm{N}$ Rasio kompos yang memenuhi standar kualitas kompos menurut Keputusan Menteri Pertanian Nomor 261/KPTS/SR.310/M/4/2019 dengan kadar minimum $15 \%$

Jika dibandingkan dengan penelitian Ellya (2020) dimana nilai kandungan C/N rasio pada pengomposan eceng gondok saja sebesar $24,05 \%$ maka dalam penelitian ini memiliki hasil $\mathrm{C} / \mathrm{N}$ rasio lebih kecil, yaitu sebesar $15,25 \%$ selama 16 hari waktu pengomposan. Hal ini diduga karena adanya perbedaan jumlah bahan baku pembuatan pupuk organik . Pada Reaktor 3 terdapat 3 jenis bahan baku dibandingkan dengan penelitian Ellya (2020) berisi 1 jenis bahan baku, dengan sistem pengomposan dan bioaktivator yang sama .

$\mathrm{C} / \mathrm{N}$ rasio akan mempengaruhi ketersediaan unsur hara pada pupuk organik, jika nilai kandungan $\mathrm{C} / \mathrm{N}$ rasio tinggi maka kandungan unsur hara hanya tersedia dalam jumlah kecil untuk tanaman. Apabila bahan organik mempunyai kandungan $\mathrm{C} / \mathrm{N}$ mendekati atau sama dengan $\mathrm{C} / \mathrm{N}$ tanah yaitu sebesar 10-12 maka bahan tersebut dapat di- gunakan atau diserap tanaman (Sitompul, 2017).

Menurut Surya (2013), semakin tinggi nilai $\mathrm{C} / \mathrm{N}$ rasio berarti bahan baku pupuk organik belum terurai dengan sempurna dengan kata lain belum matang.

\subsection{Pengaruh Kombinasi Bahan Baku terhadap Hara Makro Phospor (P)}

Pengukuran unsur phosphor (P) penting dilakukan karena phosphor $(\mathrm{P})$ penting untuk pertumbuhan tanaman. Lamanya proses pengomposan pupuk organik menentukan tinggi rendahnya kadar $\mathrm{P}$, namun semakin lama waktu pengomposan bukan berarti kadar $\mathrm{P}$ juga semakin bertambah, hal ini karena mikroorganism pada proses dekomposisi memiliki fase stasioner. Seperti yang terjadi pada penelitian Masnur ( 2016), kandungan kadar Phospor (P) pada pengomposan (eceng gondok + pupuk kandang sapi) selama 30 hari yang paling tinggi sebesar $0,72 \%$ dan yang rendah sebesar $0,47 \%$, sedangkan dalam penelitian ini nilai kandungan phosphor tertinggi sebesar 4,88\%.

Kadar phospor (P) pada proses pengomposan dengan variasi bahan baku eceng gondok, kotoran sapi, dan dedak padi dapat dilihat pada Gambar 2 di bawah ini:

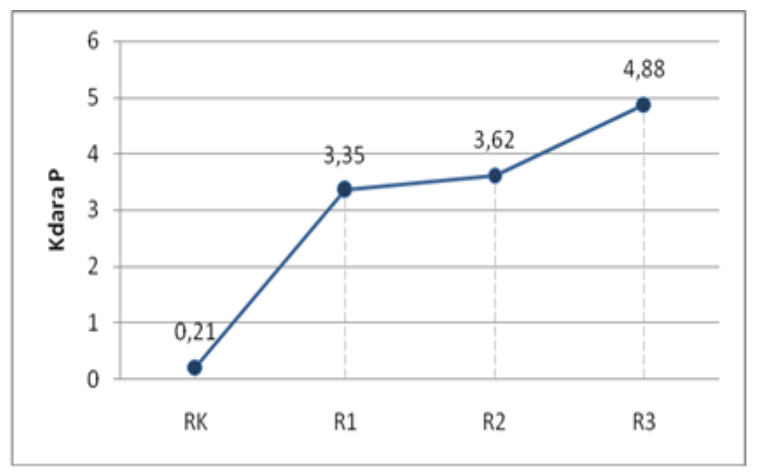

Gambar 2. Pengaruh Variasi Bahan Baku terhadap Kadar Phospor (P)

Berdasarkan hasil pengamatan diatas, menunjukkan pengaruh jumlah bahan baku memberikan hasil yang signifikan terhadap kadar Phospor (P). Kandungan phospor terendah sebesar $0,21 \%$ terbentuk pada reaktor kontrol (RK), dimana kandungan sebesar itu tidak memenuhi standar baku mutu.

Menurut Kusumawati (2011), keter-sediaan phospor (P) dipengaruhi oleh $\mathrm{pH}$. Bila $\mathrm{pH}$ bersifat alkalis, maka ion $\mathrm{HPO}_{4}^{-2}$ yang lebih dominan. Sebaliknya bila bersifat asam, maka ion $\mathrm{H}_{2} \mathrm{PO}_{4}^{-2}$ yang lebih dominan. Dalam penelitian ini ion $\mathrm{H}_{2} \mathrm{PO}_{4}^{-2}$ lebih dominan karena 
harga $\mathrm{pH}$ diatas 2. Pada reaktor 1, 2, dan 3, kandungan Phospor (P) telah memenuhi baku mutu Keputusan Menteri Pertanian Nomor 261/KPTS/SR.310/M/4/2019 dengan kadar minimum 2\%

Menurut Masnur (2016) kandungan $\mathrm{P}_{2} \mathrm{O}_{5}$ sejalan dengan kandungan $\mathrm{N}$ dalam kompos, kandungan $\mathrm{N}$ berkaitan dengan jumlah mikroorganisme yang tumbuh. Semakin besar nitrogen yang dikandung maka multiplikasi mikroorganisme yang merombak fosfor akan meningkat, sehingga kandungan fosfor dalam bahan kompos juga meningkat.

Kandungan phospor tidak bergantung pada pemberian bioaktivator (Manuputty, 2012).

\subsection{Pengaruh Kombinasi Bahan Baku Terhadap Kadar Makro Hara Kalium (K) \\ Menurut Apriliani, dkk (2016)} pengukuran kalium penting untuk dilakukan karena kalium merupakan unsur hara makro terbesar setelah $\mathrm{N}$ yang paling banyak diserap tanaman. Selain itu kalium berfungsi dalam fotosintesis sehingga mempercepat penebalan dinding-dinding sel dan ketegaran tangkai bunga, buah dan cabang.

Selama proses dekomposisi, unsur $\mathrm{K}$ dalam bahan organik kompleks di ubah oleh bakteri pelarut phospat menjadi unsur $\mathrm{K}$ organik sederhana dalam bentuk ion $\mathrm{K}^{+}$. Unsur Kalium pada bahan baku pupuk organik membantu proses metabolisme mikroba dan berfungsi sebagai katalisator proses dekomposisi (Iliyin, 2012). Kandungan $\mathrm{K}_{2} \mathrm{O}$ pupuk organik berasal dari bahan baku yang mengandung hijau daun (Astuti, dkk, 2008)

Kadar kalium $(\mathrm{K})$ pada pengaruh variasi bahan baku dapat dilihat pada Gambar 3 dibawah ini:

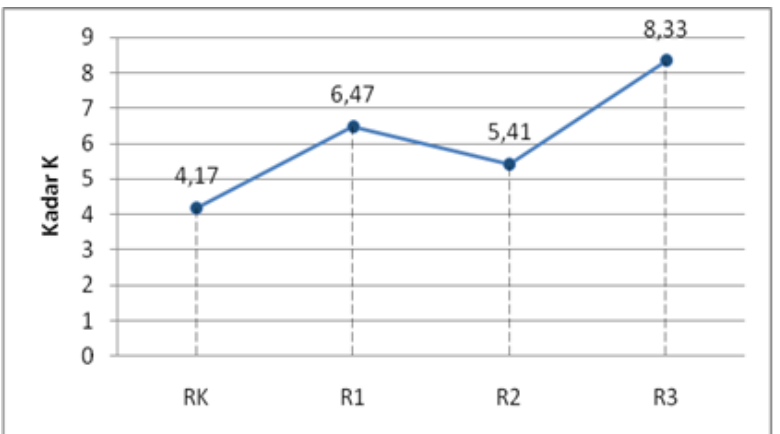

Gambar 3. Pengaruh Variasi Bahan Baku terhadap Kadar Makro Hara Kalium (K)

Kandungan Kalium (K) pada setiap reaktor adalah RK : 4,17\%, R1 : 6,47\%, R2 : 5,41\%, dan
R3 : 8,33\%. Kandungan Kalium (K) telah memenuhi standar baku mutu menurut

Keputusan Menteri Pertanian Nomor 261/KPTS/SR.310/M/4/2019 dengan nilai minimum $2 \%$

Pupuk organik yang memiliki kandungan Kalium (K) tertinggi ada pada reaktor tiga (R3) dan kandungan Kalium (K) yang terendah adalah reaktor kontrol (RK). Hal ini menunjukkan bahwa variasi bahan baku $0,5 \mathrm{~kg}$ eceng gondok $+1 \mathrm{~kg}$ kotoran sapi $+1 \mathrm{~kg}$ dedak padi dengan $200 \mathrm{~mL}$ EM4 menghasilkan pupuk organik dengan hara makro kalium yaitu diatas $2 \%$. Terjadi perubahan signifikan sebagai hasil proses pengkomposan karena kandungan kalium awal pada eceng gondok adalah sebesar 1,8\%, dan kotoran sapi sebesar 2,00\%.

Dibandingkan dengan penelitian Masnur (2016) dimana nilai kalium tertinggi pada pengomposan (eceng gondok dan pupuk kandang sapi) tanpa tambahan dedak , selama 30 hari pengomposan adalah sebesar 5,02\%. Nilai kandungan kalium dalam penelitian ini lebih tinggi yaitu sebesar 8,33\% (R3) . Hasil yang diperoleh dalam penelitian ini telah memenuhi baku mutu sesuai dengan standar Keputusan Menteri Pertanian Nomor 261/KPTS/SR.310/M/4/2019 tentang persyaratan teknis minimal pupuk organik, pupuk hayati, dan pembenahan tanah bahwa persyaratan teknik minimal pupuk organik padat yaitu sebesar minimal $2 \%$.

\subsection{Hasil Pengamatan pH}

Pengamatan $\mathrm{pH}$ dilakukan pada hari ke-7 proses pengkomposan, hasil pengamatan dapat dilihat pada Gambar 4 dibawah ini:

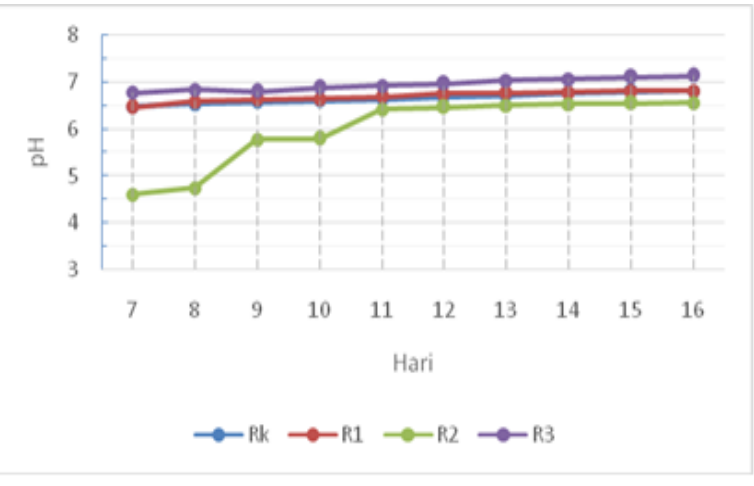

Gambar 4. Hasil Pengamatan terhadap pH

Nilai $\mathrm{pH}$ terus mengalami peningkatan setiap harinya yaitu berkisar antara 4,60 - 7,14. Hal ini berbeda dengan hasil penelitian Khater (2015) terhadap pengomposan kotoran sapi dimana diperoleh $\mathrm{pH}$ akhir kompos sebesar 8,1 . 
Pada reaktor 3 pada hari ke-9 sedikit menurun, kondisi ini di duga karena aktivitas mikroorganisme yang menguraikan bahan organik (Masnur, 2016 dan Siagian, 2021). Kenaikan pH juga dapat disebabkan karena amonia yang diproduksi pada saat proses dekomposisi. Hal ini sesuai dengan penelitian yang dilakukan oleh Widarti, dkk (2015), pH kompos yang naik menunjukkan bahwa adanya amonia dan aktivitas mikroba yang mempengaruhi kenaikan $\mathrm{pH}$ kompos. Pada semua reaktor nilai kadar $\mathrm{pH}$ sesuai dengan standar baku mutu menurut Keputusan menteri pertanian Nomor 261/KPTS/SR.310/M/4/ 2019 yaitu pada rentangan 4-9.

Menurut Ramadhan (2016) pengamatan $\mathrm{pH}$ kompos berfungsi sebagai indikator berlangsungnya proses dekomposisi. Mikroorganisme akan bekerja pada keadaan $\mathrm{pH}$ netral sampai sedikit masam, dengan derajat keasaman berkisar antara 5,5 sampai 8 . Kondisi asam ini dapat mendorong pertumbuhan jamur yang akan mende-komposisi lignin dan selulosa pada bahan kompos.

\subsection{Hasil Pengamatan Suhu}

Pengukuran suhu digunakan sebagai salah satu parameter fisik untuk mengetahui tingkat kematangan saat proses pengomposan (Jodar dkk, 2017). Indikator terjadinya proses peruraian bahan organik di dalam proses pengkomposan adalah terjadinya peningkatan suhu (Widarti, dkk, 2015). Untuk memastikan kestabilan suhu kompos maka dilakukan pengamatan di beberapa titik tumpukan kompos. Peningkatan suhu kompos disebabkan adanya aktifitas bakteri dan jamur mesofilik. Pengamatan pada suhu dilakukan pada hari ke-7 proses pengkomposan, dijelaskan pada Gambar 5 dibawah ini:

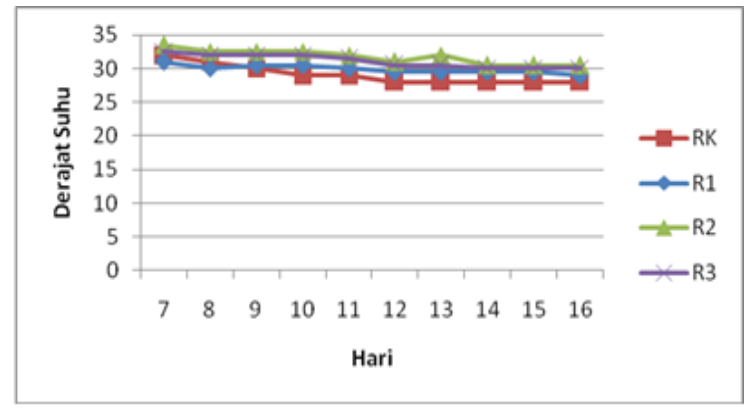

Gambar 5. Hasil Pengamatan Suhu

Pada gambar 5 diatas menunjukkan bahwa suhu pupuk organik mengalami penurunan. Suhu optimum yang dicapai pada pengomposan hari ke-7. Pada reaktor kontrol
(RK) sebesar $32^{\circ} \mathrm{C}$, pada reaktor 1 (R1) sebesar $31^{\circ} \mathrm{C}$, pada reaktor 2 (R2) sebesar 33,5을 dan pada reaktor 3 (R3) sebesar 32,5. Memasuki hari ke-8 sampai ke-14 suhu pengomposan mulai menurun pada setiap reaktor dan mulai stabil pada hari ke-15 yaitu berkisar antara $28^{\circ} \mathrm{C}-30^{\circ} \mathrm{C}$. Suhu pada akhir pengomposan yaitu hari ke-16 sudah sesuai dengan standar kualitas kompos menurut SNI yaitu $20^{\circ} \mathrm{C}-30^{\circ} \mathrm{C}$.

Penurunan suhu tersebut terjadi, dan tidak tercapainya suhu termofilik $\left(40^{\circ}-65^{\circ} \mathrm{CO}\right.$ di karenakan jumlah limbah yang dikomposkan sedikit, sehingga tidak cukup memberikan insulasi panas. Panas di lepaskan ke alam, sehingga menyebabkan suhu pengkomposan turun (Widarti, dkk, 2015). Aktifitas mikroba mesofilik pada saat proses penguraian akan menghasilkan panas dengan mengeluarkan $\mathrm{CO}_{2}$ dan mengambil $\mathrm{O}_{2}$ dalam tumpukan pupuk organik, sehingga akan tercapai suhu maksimum.

Hal ini sesuai dengan yang dikemukakan oleh Kusumawati (2011) bahwa selama proses pengomposan suhu yang awalnya normal dalam tumpukan kompos secara bertahap mengalami peningkatan dan akan mencapai suhu maksimum kemudian akan menurun sampai menjadi stabil pada saat kompos matang.

Menurut Yuwono et al. (2006), suhu rata rata selama proses pengomposan berkisar antara $27-36^{\circ} \mathrm{C}$. Suhu maksimum dicapai pada minggu ke-2, setelah itu suhu berangsur turun dan akhirnya konstan sesuai dengan suhu lingkungannya.

\section{KESIMPULAN}

Penelitian menunjukkan bahwa Reaktor perlakuan 3 (RK3) memiliki nilai $\mathrm{C} / \mathrm{N}$ rasio tertinggi yaitu sebesar 15,25 \%, demikian pula denagn kandungan unsur hara makro $P$ sebesar 4,88\% dan $\mathrm{K}$ sebesar $8,33 \%$, nilai tersebut diatas batas minimal sebesar $2 \%$ sesuai baku mutu dalam Keputusan Menteri Pertanian Nomor 261/KPTS/SR.310/M/4/ 2019. pH dalam pembuatan pupuk organik cenderung meningkat setiap harinya yaitu berkisar antara 4,60 - 7,14, masih dalam rentangan $\mathrm{pH}$ baku mutu Keputusan Menteri Pertanian Nomor 261/KPTS /SR.310/M/4/2019. Suhu akhir pada semua reaktor pada pupuk organik dalam penelitian ini yaitu antara $29^{\circ} \mathrm{C}-30^{\circ} \mathrm{C}$ sesuai dengan persyaratan suhu pupuk organik dalam SNI 
19-7030-2004 tenatng Spesifikasi Kompos dari Sampah Organik Domestik.

\section{DAFTAR PUSTAKA}

Apriliani, Ii. N., Heddy, S., \& Suminarti, N. E. (2016). Pengaruh kalium pada pertumbuhan dan hasil dua varietas tanaman ubi jalar (Ipomea batatas (L.) Lamb). Jurnal Produksi Tanaman, 4(4), 264-270.

http://protan.studentjournal.ub.ac.id/i ndex.php/protan/article/view/290

Astuti, H. Y., Harlian, E., dan Tanti, M. E. (2008). Upaya Pengolahan Feses Domba dan Limbah Usar (Vitiveria zizanioides) melalui Berbagai Metode Pengomposan. Jurnal Ilmu Ternak, 8(1): 87-90.

Badan Penelitian dan Pengembangan Pertanian, (2008), Sekam Padi sebagai Sumber Energi Alternatif dalam Rumah Tangga Petani, Penerbit LPP, Yogyakarta.

Ellya, Hikma, Ronny Mulyawan dan Novianti Adi Rohmanna, 2020, Potensi Tumbuhan Lahan Rawa Sebagai Pupuk Organik, Agrisains: Jurnal Budidaya Tanaman Perkebunan Politeknik Hasnur 2020, 6(1), 13-17 ISSN 25033239

Elystia, S., Yenie, E., Ari Rahmat Mustakim, \& Mansandi, D. (2013). Pemanfaatan Sampah Organik Pasar dan Kotoran Sapi Menjadi Biogas Sebagai Alternatif Energi Biomassa. Jurnal Prosiding, 1(3), 166-172.

Heckman, J. J., Pinto, R., \& Savelyev, P. A. (2019). Pengaruh Fermentasi Menggunakan Mikroba Cairan Rumen Sapi Terhadap Komposisi Kimia Dedak Padi. Jurnal Peternakan Lahan Kering, 1(4), 562-569.

Heyne, K. (1987). Tumbuhan Berguna Indonesia Jilid II. Badan Penelitian dan Pengembangan Kehutanan. Departemen Kehutanan. Bogor.

Hidayati, Y. A., Kurnani, T. B. A., Marlina, E. T., \& Ellin, H. (2011). Kualitas Pupuk Cair Hasil Pengolahan Feses Sapi Potong Menggunakan Saccharomyces cereviceae. Jurnal Ilmu Ternak, 11(2), 104-107.

Iliyin M., Roko, K., dan Nurul, P. (2012). Laju Dekomposisi Eceng Gondok dan Jerami Menggunakan EM-4 dan M-NIO terhadap pH, C, N, P, K dan C/N. Jurnal Media Sains, 4(2): 117122.

Indonesia, K. M. P. R. (2019). Persyaratan Teknis Minimal Pupuk Organik, Pupuk Hayati, dan Pembenah Tanah. In Keputusan Menteri Pertanian Republik Indonesia No 261 (pp. 1-18). http://psp.pertanian.go.id/index.php/ page/publikasi/418

Juliani, R., Ronauli Simbolon, R. F., Sitanggang, W. H., \& Aritonang, J. B. (2017). Pupuk Organik Enceng Gondok Dari Danau Toba. Jurnal Pengabdian Kepada Masyarakat, 23(1), 220-224. https://doi.org/10.24114/jpkm.v23i1. 6637

Karyono, T., Maksudi, \& Yatno. (2017). Penambahan Aktivator Mol Bonggol Pisang dan EM 4 dalam Campuran Feses Sapi Potong dan Kulit Kopi terhadap Kualitas Kompos dan Hasil Panen Pertama Rumput Setaria (Setaria splendida Stapf). Jurnal Sains Peternakan Indonesia, 12(1), 102-111.

Kleden, M. M., \& Soetanto, H. (2017). Concentration of Progesterone and Prolactin Hormones and Milk Production of New Zealand White Rabbits Doe Fed Moringa Leaves Meal. Journal of Social Sciences, 8(3), 79-85. https://doi.org/10.5901/mjss.2017.v8 n3p79

Kusrinah, Alwiyah N, Nur H., (2016), Training and Assistance of Water Hyacinth Utilization (Eichhornia crassipes) beco-me liquid compost fertilizer to reduce water pollution and improve economy of Karangkimpul village community of Kaligawe Subdistrict Gayamsari District, Semarang Municipality, Journal Dimas 16 (1) : 27-48.

Kusumawati, N. (2014). Evaluasi Perubahan Temperatur, $\mathrm{Ph}$ Dan Kelembaban Media Pada Pembuatan Vermikompos Dari Campuran Jerami Padi Dan Kotoran Sapi Menggunakan Lumbricus Rubellus. Jurnal Inotek, 15(1), 45-56.

Magna Kusuma, A. P., Biyantoro, D., \& Margono, M. (2017). Pengaruh Penambahan EM-4 dan Molasses terhadap Proses Composting Campuran Daun Angsana (Pterocarpus indicun) dan Akasia (Acasia auriculiformis). Jurnal Rekayasa Proses, 11(1), 
https://doi.org/10.22146/jrekpros.19 145

Mashavira M, Mhindu L M, Muzemu S, C. T. and M. P. (2014). The effect water hyacinth (Eichhornia crassipes, L) compost application on heavy metal concentration and agronomic performance of cabbage. Journal of Science, 5(1), 121-132.

Melsasail, L., \& Kamagi, Y. E. B. (2019). Analisis Kandungan Unsur Hara Pada Kotoran Sapi Di Daerah Dataran Tinggi Dan Dataran Rendah. Jurnal Lingkungan, 2(6), 1-15.

Nengse, S. (2009). Pengaruh Penambahan Kompos Pada Tanah Untuk Mengurangi Genangan Di Kelurahan Bulak, Kecamatan Kenjeran, Kota Surabaya. Jurnal Teknik Lingkungan, 2(2), 46-52.

Palupi, N. P. (1967). Karakter Kimia Kompos Dengan Dekomposer Mikroorganisme Lokal Asal Limbah Sayuran. Jurnal Ziraa'ah, 40, 5-48.

Ratnaningsih, Widyatmoko, H., \& Yananto, T. (2009). Potensi pembentukan biogas pada proses biodegradasi campuran sampah organik segar dan kotoran sapi dalam batch reaktor anaerob. Jurnal Teknologi Lingkungan, 5(1), 19-26.

Siagian, S. W., Yuriandala, Y., \& Maziya, F. B. (2021). Analisis Suhu, Ph Dan Kuantitas Kompos Hasil Pengomposan Reaktor Aerob Termodifikasi Dari Sampah Sisa Makanan Dan Sampah Buah. Jurnal Sains \&Teknologi Lingkungan, 13(2), 166-176.

https://doi.org/10.20885/jstl.vol13.is s2.art7

Sitompul, E., Wardhana, I. wisnu, \& Sutrisno, E. (2017). Studi Identifikasi Rasio C/N Pengolahan Sampah Organik Sayuran Sawi, Daun Singkong, Dan Kotoran Kambing Dengan Variasi Komposisi Menggunakan Metode Vermikomposting. Jurnal Teknik Lingkungan, 56(2), 1-12.

Sittadewi, E. H. (2007). Eceng Gondok Menjadi Media Tumbuh Untuk Mendukung Pertanian Organik. Jurnal Teknologi Lingkungan, 8(3), 229-234.

Surya, R, S., S. (2013). Pengaruh Pengomposan Terhadap Rasio C/N Kotoran Ayam Dan Kadar Hara NPK Tersedia Serta Kapasitas Tukar Kation Tanah. Journal of Chemistry, 2(1), 137144.
SNI 19-7030-2004 Spesifikasi Kompos dari Sampah Organik Domestik

Tripetchkul, S., Pundee, K., Koonsrisuk, S., \& Akeprathumchai, S. (2012). Cocomposting of coir pith and cow manure: initial $\mathrm{C} / \mathrm{N}$ ratio vs physicochemical changes. International Journal of Recycling of Organic Waste in Agriculture, 1(1).

Wizna, W., \& Muis, H. (2012). Pemberian Dedak Padi yang Difermentasi dengan Bacillus amyloliquefaciens sebagai Pengganti Ransum Komersil Ayam Ras Petelur. Jurnal Peternakan Indonesia (Indonesian Journal of Animal Science), 14(2), 398.

Wulandari, D. A., Linda, R., \& Turnip, M. (2016). Kualitas Kompos dari Kombinasi Eceng Gondok ( Eichornia crassipes Mart. Solm) dan Pupuk Kandang Sapi dengan Inokulan Trichoderma harzianum L. Jurnal Protobiont, 5(2), 34-44.

Yani, H., Rahmawati, \& Rahmi, F. (2018). Kualitas Fisika dan Kimia Kompos Eceng Gondok (Euchornia crasipess) Menggunakan EM-4. Jurnal Konversi, $7(2), 1-8$.

Yuwono, 2006, Kecepatan Dekomposisi dan Kualitas Kompos Sampah Organik, Jurnal Inovasi Pertanian Vol 4 No2. Hal $116-123$. 